\title{
Some anabolic aspects of protein metabolism in riboflavin deficiency in the rat*
}

\author{
By SAILEN MOOKERJEA† \\ (Post-Doctorate Fellow, 1956-7, National Research Council of Canada)
}

AND W. W. HAWKINS

Atlantic Regional Laboratory, National Research Council of Canada, Halifax, Nova Scotia, Canada

\section{(Received 25 Fuly I959-Revised 25 Fanuary 1960)}

Flavin nucleotides are components of certain enzyme systems which are involved in the oxidation of nitrogenous compounds, including at least some of the amino acids. The oldest and best-known evidence for this relationship was derived from studies of biochemical systems in vitro, but it is also supported by the results of studies on intact animals. For example, Burch, Lowry, Padilla \& Combs (1956) showed that when rats were deprived of riboflavin for 6 weeks the activities of xanthine oxidase and of several amino-acid oxidases in their livers were substantially reduced.

Kaunitz, Wiesinger, Blodi, Johnson \& Slanetz (1954) observed that the deleterious effects of riboflavin deficiency on rats were more pronounced the higher the intake of protein, and concluded that riboflavin and protein are mutually limiting factors in nutrition. It has also been shown that on a diet low in protein the riboflavin content of the organs of rats decreases (McQuarrie \& Venosa, I945; Czaczkes \& Guggenheim, 1946), regardless of the intake of the vitamin, and that the urinary excretion of it increases (Czaczkes \& Guggenheim, 1946). With higher intakes of protein, however, the amount of the vitamin in organs was found to increase as its urinary excretion decreased (Czaczkes \& Guggenheim, 1946). There have been other reports (Sarett \& Perlzweig, I943; Sherman \& Ragan, I947) that rats retain riboflavin in proportion to the intake of protein, and Sarett, Klein \& Perlzweig (1942) showed that when positive nitrogen balance was induced in dogs and rats less riboflavin was excreted from test doses than when the nitrogen balance was negative.

None of these findings are necessarily at variance with the role of riboflavin in katabolic processes in protein metabolism. On the other hand, they do not contradict the concept that it is involved in anabolic processes, for which there is also direct evidence.

Kleiber \& Jukes (1942) observed that chicks deficient in riboflavin stored about $30 \%$ less of their dietary nitrogen than pair-fed controls, and the difference was reflected in their body-weight, which would indicate that the nitrogen storage was

* Issued as N.R.C. no. 5657. Presented in part at the 2 Ist Annual Meeting of the Canadian Physiological Society in Ottawa in June 1957, and at the 2 Ist International Congress of the Physiological Sciences in Buenos Aires in August 1959.

$\dagger$ Present address: University Department of Biochemistry, University of Nagpur, Nagpur, India. 
associated with the synthesis of protein. Borgström \& Hammarsten (I944) found that in rats the intake of riboflavin was directly related to the degree of nitrogen storage and to the ratio of gain in weight to food intake. Mayfield \& Hedrick (1949) found essentially the same, but calculated the response in terms of the biological value of the dietary protein, which increased with increasing riboflavin intake. Frei \& Ryser (1956) found that in riboflavin-deficient rats there was a substantial decrease in the amount of protein in liver mitochondria.

Some of the more recent work of Guggenheim \& Diamant (1959) has provided information of particular importance for assessing this relationship. They found that in riboflavin deficiency in the rat the concentration of nitrogen in the liver was not affected, but that the liver was enlarged; and there was a decrease in the concentration of nitrogen in the carcass. Consequently the liver contained more nitrogen per unit of body-weight, and a higher proportion of the total nitrogen of the body. In comparison with various types of control animals, the proportion of nitrogen in the body did not differ importantly, but more of it was present in the liver. These observations point to an alteration of protein metabolism in riboflavin deficiency, characterized by what could be an impairment of the anabolic processes in muscle, and an enhancement of them in the liver. This effect is important, because there is much evidence that the protein of liver, or at least an important fraction of it, is particularly labile, and sensitive to dietary depletion and repletion (Addis, Poo \& Lew, 1936a-c; Kosterlitz, 1944; Harrison \& Long, 1945; Stanier, 1957). It could reasonably be expected, therefore, that this particularly active component of the body's protein-producing system would be highly sensitive to a deficiency of any factor such as a vitamin that may be involved in an anabolic process. If it is so the findings of Guggenheim \& Diamant (1959) do not indicate such a role for riboflavin.

The variations and conflict among these many diverse findings have produced a confused picture of the overall or resultant effect of riboflavin deficiency upon protein metabolism. That the question is of interest is attested by the amount of experimental work that has been devoted to it, and it is of importance because of the implication of a quantitative relationship between two nutrients.

We undertook the experiments herein described to obtain more information on this relationship, particularly concerning the importance to protein synthesis of an adequate supply of riboflavin. We measured the levels of liver nitrogen and of blood proteins in rats after growth impairment by deprivation of riboflavin. In some it was done after a short period of rapid protein repletion when the activity of the anabolic processes had been increased by previous protein depletion.

\section{EXPERIMENTAL}

The percentage composition of the diets used in the experiments was: vitamin-test casein 0,16 , and 40 , with corresponding content of sucrose of 85,69 and 45 ; cellulose flour 4; maize oil 7; salt mixture (Wesson's (1932) modification of the Osborne \& Mendel salt mixture, purchased as Salt Mixture $W$ from Nutritional Biochemicals Corporation, Cleveland, Ohio) 4 . To every $100 \mathrm{~g}$ of this mixture were added: cod- 
liver oil concentrate (Ayerst, McKenna \& Harrison Ltd (Montreal) Special Formula no. 33 IOI) $0.2 \mathrm{mg}$ (40 i.u. vitamin A and ro i.u. vitamin D), $\alpha$-tocopheryl acetate $3 \mathrm{mg}$, menaphthone $0.2 \mathrm{mg}$, choline chloride $100 \mathrm{mg}$, inositol $50 \mathrm{mg}$. Water-soluble vitamins were given to each rat daily by subcutaneous injection: thiamine hydrochloride $12.5 \mu \mathrm{g}$, pyridoxine hydrochloride $10 \mu \mathrm{g}$, calcium pantothenate $100 \mu \mathrm{g}$, nicotinic acid $20 \mu \mathrm{g}$, biotin $2 \mu \mathrm{g}$, folic acid $2 \mu \mathrm{g}$, vitamin $\mathrm{B}_{12} 0.01 \mu \mathrm{g}$. Those rats in control groups were given in addition $25 \mu \mathrm{g}$ riboflavin.

Young male and female rats of the Wistar strain were used, sixty in each of three experiments, and $\mathrm{I}_{7} 7$ in a fourth. Their weights ranged between 70 and 90 () or between 80 and $100\left(\delta^{3}\right) \mathrm{g}$. They were divided equally among three groups so that the mean body-weight of those in each was the same. The animals in groups A and B were given riboflavin, and those in group $\mathrm{C}$ were not. The last showed varying degrees of anorexia with time, and impairment of growth when compared with the animals of group A, which were maintained on the same amount of food. The animals of group B were given smaller amounts of food, to keep their weights similar to those of group C. All animals were maintained individually in screen-bottomed cages. Water was supplied to them ad lib. The rats were given the diet containing $16 \%$ protein for $45^{-76}$ days, at which times the mean body-weight of group A differed from that of groups $\mathrm{B}$ and $\mathrm{C}$ by $10-15 \%$.

Expts $I$ and 2 were terminated at this stage. In both, the livers and samples of blood, and in Expt 2 the kidneys also, were taken for analysis. At a corresponding stage in Expt 3 eight rats from each group, A, B and C, were killed. The rest were depleted of protein by dietary deprivation for 21 days, and moderate haemorrhage was imposed on the last day to deplete further the body proteins. On the following day four animals from each group were killed. The rest were put on the diet containing $40 \%$ protein for a repletion period of 3 days, after which they were killed. After the animals were killed the livers and samples of blood were obtained for analysis. In Expt 4 the procedure was similar to that in Expt 3, but only half the animals were subjected to haemorrhage at the end of the period of dietary deprivation of protein. Two sets of results were thus obtained from this experiment, determined by whether haemorrhage was imposed $(b)$ or not $(a)$. The numbers of animals for which information was obtained at each stage, in the same order as noted for the preceding experiment, were five to seven, six, and eight to ten, for both $(a)$ and $(b)$.

Haemorrhage was accomplished by immersing the tail in warm oxalate solution after the end had been cut off. Blood equivalent to $2 \%$ of the body-weight was removed, after which the animal was given intraperitoneally $5 \mathrm{ml}$ physiological saline solution.

The rats were killed with pentobarbital sodium and diethyl ether. They were weighed, as were also the livers and kidneys, and weight relationships between the organs and the body were calculated. Blood was taken from the heart, and oxalated.

Haemoglobin was determined by a methaemoglobin method (Collier, 1944), and plasma protein by a biuret method (Gornall, Bardawill \& David, 1949). Liver and kidneys were made into 'breis' with water, and their total nitrogen was determined by a titrimetric micro-Kjeldahl method (Sobel, Mayer \& Gottfried, 1944; Hiller, Plazin \& 
Van Slyke, 1948). In Expt 2 the proportion of solid material in liver was calculated from the weight of residues from portions of the brei heated to constant weight at $80^{\circ}$ in a draught oven.

To evaluate the difference between some of the mean values obtained Student's $t$ test was used, as applied to small samples (Davenport \& Ekas, 1936).

\section{RESULTS}

Tables $\mathrm{I}$ and $\mathbf{2}$ show that in the rat the concentrations of blood haemoglobin, plasma protein, and liver and kidney nitrogen are not affected by riboflavin insufficiency over a period long enough substantially to impair the growth of the animals. In the riboflavin-deficient rats there was a tendency for the liver to assume a greater proportion of the body-weight. Consequently the liver content of nitrogen in relation to bodyweight tended to be greater in these animals than in those with adequate riboflavin. This finding is consistent with those of Guggenheim \& Diamant (1959). If this

Table I. Expt $\mathrm{I}$. Weight and nitrogen content of livers, and concentration of plasma proteins, of rats after 57 days on a diet containing $16 \%$ protein

(Mean values and ranges)

\begin{tabular}{|c|c|c|c|c|c|}
\hline \multirow[b]{3}{*}{ Nutritional state } & \multirow[b]{3}{*}{$\begin{array}{l}\text { No. of } \\
\text { rats }\end{array}$} & \multicolumn{3}{|c|}{ Liver } & \multirow{3}{*}{$\begin{array}{c}\text { Plasma } \\
\text { protein } \\
\text { content } \\
(\mathrm{g} / \mathrm{I} 00 \mathrm{ml})\end{array}$} \\
\hline & & \multirow{3}{*}{$\begin{array}{c}\text { Fresh } \\
\text { weight } \\
\text { as } \% \text { of } \\
\text { body-weight } \\
3 \cdot 3 \\
(2 \cdot 9-3 \cdot 7)\end{array}$} & \multicolumn{2}{|c|}{ Nitrogen content } & \\
\hline & & & $\begin{array}{l}\mathrm{g} / \mathrm{I} \text { oo } \mathrm{g} \\
\text { liver }\end{array}$ & $\begin{array}{c}\mathrm{mg} / \mathrm{I} 00 \mathrm{~g} \\
\text { body-weight }\end{array}$ & \\
\hline A (food controls) & 20 & & $\begin{array}{c}3 \cdot 4 \\
(3 \cdot 2-3 \cdot 7)\end{array}$ & $\begin{array}{c}113 \\
(103-120)\end{array}$ & $\begin{array}{c}3 \cdot 8 \\
(3 \cdot 4-4 \cdot 3)\end{array}$ \\
\hline B (weight controls) & 20 & $\begin{array}{c}3 \cdot 1 \\
(2 \cdot 7-3 \cdot 5)\end{array}$ & $\begin{array}{c}3 \cdot 5 \\
(3 \cdot 2-3 \cdot 7)\end{array}$ & $\begin{array}{c}110 \\
(103-118)\end{array}$ & $\begin{array}{c}3 \cdot 9 \\
(3 \cdot 5-4 \cdot 7)\end{array}$ \\
\hline $\mathrm{C}$ (riboflavin-deficient) & 20 & $\begin{array}{c}3 \cdot 8 \\
(3 \cdot 2-4 \cdot 9)\end{array}$ & $\begin{array}{c}3 \cdot 5 \\
(2 \cdot 9-4 \cdot 4)\end{array}$ & $\begin{array}{c}134 \\
(111-159)\end{array}$ & $\begin{array}{c}3 \cdot 6 \\
(2 \cdot 8-4 \cdot 3)\end{array}$ \\
\hline $\begin{array}{l}\text { Significance of } \\
\text { difference between } \\
\mathrm{A} \text { and } \mathrm{C}\end{array}$ & - & $P<0.01$ & $\longrightarrow$ & $P<0.01$ & - \\
\hline
\end{tabular}

Table 2. Expt 2. Weight and nitrogen content of livers and kidneys, and concentrations of blood haemoglobin and plasma proteins, of rats after $5^{1}$ days on a diet containing $16 \%$ protein

(Mean values and ranges)

\begin{tabular}{|c|c|c|c|c|c|c|c|c|c|c|}
\hline \multirow[b]{2}{*}{$\begin{array}{c}\text { Nutritional } \\
\text { state }\end{array}$} & \multirow[b]{2}{*}{$\begin{array}{l}\text { No. of } \\
\text { rats }\end{array}$} & \multicolumn{4}{|c|}{ Liver } & \multicolumn{3}{|c|}{ Kidneys } & \multirow[b]{2}{*}{$\begin{array}{c}\text { Blood } \\
\text { haemo- } \\
\text { globin } \\
\text { content } \\
(\mathrm{g} / \mathrm{l} 00 \mathrm{ml})\end{array}$} & \multirow[b]{2}{*}{$\begin{array}{r}\text { Plasma } \\
\text { protein } \\
\text { content } \\
(\mathrm{g} / 100 \mathrm{ml})\end{array}$} \\
\hline & & $\begin{array}{c}\text { Dry- } \\
\text { matter } \\
\text { content } \\
(\%)\end{array}$ & $\begin{array}{c}\text { Fresh } \\
\text { weight as } \\
\% \text { of } \\
\text { body- } \\
\text { weight }\end{array}$ & $\begin{array}{l}\text { g/100 g } \\
\text { liver }\end{array}$ & $\frac{\text { ogen }}{\begin{array}{c}\text { mg/roo g } \\
\text { body- } \\
\text { weight }\end{array}}$ & $\begin{array}{c}\text { Fresh } \\
\text { weight as } \\
\% \text { of } \\
\text { body- } \\
\text { weight }\end{array}$ & $\overbrace{\begin{array}{l}\text { g/IOO } \mathrm{g} \\
\text { kidney }\end{array}}^{\text {Nitro }}$ & $\underbrace{\text { ogen }}_{\begin{array}{c}\text { mg/roo g } \\
\text { body- } \\
\text { weight }\end{array}}$ & & \\
\hline A (food controls) & 20 & $\begin{array}{c}30 \\
(28-32)\end{array}$ & $\begin{array}{c}3 \cdot 1 \\
(2 \cdot 8-4 \cdot 4)\end{array}$ & $\begin{array}{c}3 \cdot 1 \\
(2 \cdot 5 \cdot 3 \cdot 7)\end{array}$ & $\begin{array}{c}95 \\
(81-117)\end{array}$ & $\begin{array}{c}0.8 \\
(0.7-1.0)\end{array}$ & $\begin{array}{c}2 \cdot 7 \\
(1 \cdot 9-3 \cdot 0)\end{array}$ & $\begin{array}{c}21 \\
(14-24)\end{array}$ & $\begin{array}{c}15 \cdot 5 \\
(13 \cdot 6-16 \cdot 5)\end{array}$ & $\begin{array}{c}3 \cdot 8 \\
(3 \cdot 3-4 \cdot 5)\end{array}$ \\
\hline $\begin{array}{r}\text { B (weight } \\
\text { controls) }\end{array}$ & 20 & $\begin{array}{c}29 \\
(27-32)\end{array}$ & $\begin{array}{c}2 \cdot 8 \\
(2 \cdot 5-3 \cdot 0)\end{array}$ & $\begin{array}{c}3 \cdot 1 \\
(2 \cdot 5-3 \cdot 6)\end{array}$ & $\begin{array}{c}88 \\
(70-106)\end{array}$ & $\begin{array}{c}0.8 \\
(0.7-1.0)\end{array}$ & $\begin{array}{c}2 \cdot 6 \\
(1 \cdot 8-3 \cdot 1)\end{array}$ & $\begin{array}{c}22 \\
\left(15^{-25}\right)\end{array}$ & $\begin{array}{c}15.0 \\
(14.1-16.7)\end{array}$ & $\begin{array}{c}3 \cdot 7 \\
(3 \cdot 3-4 \cdot 5)\end{array}$ \\
\hline $\begin{array}{l}\text { C (riboflavin- } \\
\text { deficient) }\end{array}$ & 20 & $\begin{array}{c}30 \\
(27-35)\end{array}$ & $\begin{array}{c}3.5 \\
(2 \cdot 8-4 \cdot 5)\end{array}$ & $\begin{array}{c}3 \cdot 1 \\
(2 \cdot 5-3 \cdot 7)\end{array}$ & $\begin{array}{c}97 \\
(70-126)\end{array}$ & $\begin{array}{c}0.9 \\
(0.7-1 \cdot 0)\end{array}$ & $\begin{array}{c}2 \cdot 5 \\
(1 \cdot 9-2 \cdot 8)\end{array}$ & $\begin{array}{c}21 \\
(17-25)\end{array}$ & $\begin{array}{c}15.0 \\
(13.6-16 . x)\end{array}$ & $\begin{array}{c}3.6 \\
(3 \cdot 0-4 \cdot 1)\end{array}$ \\
\hline
\end{tabular}


increase were in non-protein nitrogen (NPN), it is likely that it would be reflected in an increased concentration of this fraction in the blood. In a similar experiment not described here we measured the blood NPN, and found mean values for groups A, B and $\mathrm{C}$ of $40 \cdot 6,33^{\circ} 8$ and $39.7 \mathrm{mg} / 100 \mathrm{ml}$ respectively. We therefore interpret the changes in liver nitrogen as reflections of changes in the protein.

Fig. I gives the results of the two experiments in which the regeneration of protein after protein depletion was studied. In these experiments the concentrations of the

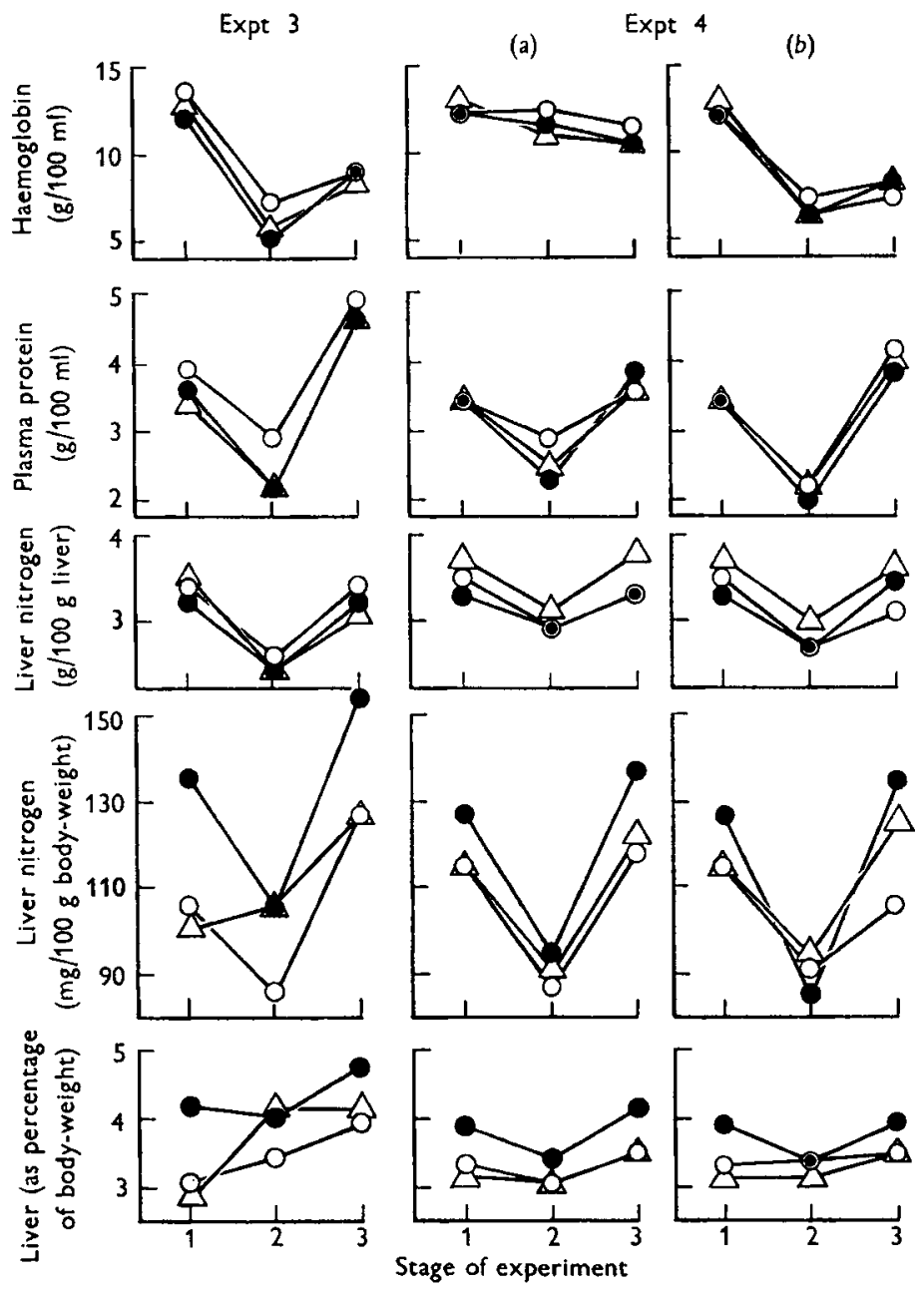

Fig. I. Effect of protein depletion and subsequent repletion on liver weight and protein content of liver and blood of rats with, or deprived of, riboflavin. Stage 1 , after 45 (Expt 3 ) or 76 (Expt 4) days on a diet with $16 \%$ protein; stage 2 , after 21 days on a protein-free diet and in Expts 3 and $4(b)$ I day after loss of blood equivalent to $2 \%$ of the body-weight; stage 3 , after 3 days on a diet with $40 \%$ protein; $0-0$, group $A$, food controls; $\Delta-\Delta$, group B, weight controls; $-\bullet$, group C, riboflavin-deficient rats. Each point is the mean for four to ten rats. For liver weight expressed as a percentage of body-weight $P$ values for difference between $C$ and $A$ or $B$ were $<0.05$ or $<0.01$ at stages $I$ and 3 in all experiments ; for weight of liver nitrogen expressed as a proportion of body-weight they were $<0^{\circ} \mathrm{oI}$ at stages 1 and 3 in Expt 3 . 
protein fractions studied were affected in the same way regardless of the state of riboflavin nutrition of the animal. The peculiarity seen in the previous experiments was again evident in the livers of the riboflavin-deficient rats. Not only before the period of protein depletion, but also in the subsequent period of repletion, the ratio of liver-weight to body-weight, and consequently of liver content of nitrogen to bodyweight, since the concentration of nitrogen was not affected, tended to be larger.

\section{DISCUSSION}

The proteins measured in these experiments are among the most important of the body proteins. That of the liver is probably the most labile and the most sensitive to depletion and repletion. In particular it would be expected that if protein synthesis is affected it would be evident in changes in this fraction when stress is put upon the anabolic system.

These experiments produced evidence that a deficiency of riboflavin in the rat does not impair the maintenance and synthesis of certain proteins of the body that are quantitatively and metabolically important. Previous findings that indicate that the state of riboflavin nutrition is directly related to nitrogen storage and to the maintenance of specific proteins do not therefore necessarily indicate that the relationship applies to all the proteins of the body. The tendency toward accumulation of more protein in the liver in riboflavin deficiency, even under conditions of active protein repletion, is particularly important. The evidence from these experiments strengthens the belief that anabolic processes in protein metabolism are not adversely affected by riboflavin deficiency.

Bartlett \& Glynn (1950) found that in hypophysectomized rats when marked increase in weight was induced by growth hormone, there was an accompanying small decrease in the size of the liver, which occurred under conditions of paired feeding. They suggested that the liver proteins were supplying material for the enlargement of other parts of the body. Our values, and those of Guggenheim \& Diamant (1959), present an opposite set of metabolic circumstances, and could be interpreted to indicate that in riboflavin deficiency, although protein synthesis may not be impaired, some transfer from liver to peripheral tissues may be. If it should be so, the function of the anterior pituitary might be involved. This possibility of impaired transfer of proteins from liver to muscle offers another explanation of our observations than that which postulates increased synthesis in liver and probably decreased synthesis in muscle.

A decreased capacity for glyconeogenesis (Reade \& Morgan, 1949; Forker \& Morgan, 1954, 1955) and an increased sensitivity to insulin (Ershoff, 1954) have been found in riboflavin-deficient rats, with evidence in each instance that they are the result of impaired adrenal cortical function, and some evidence that the function of the pituitary is involved (Forker \& Morgan, 1954, 1955).

There is evidence that cortical hormones are importantly involved in the metabolic production of carbohydrates from amino acids (Evans, 1935-6; Long, Katzin \& Fry, 1940; Long, 1942; Lewis, Thorn, Koepf \& Dorrance, 1942); therefore reduced cortical function is consistent with conservation of amino acids. On the other hand, the 
administration of cortical extract to rats has been shown to decrease the capacity of the carcass to increase its protein content (Clarke, 1953) but to increase that of the liver (Clarke, 1953; Roberts, 1953). Guggenheim \& Diamant (1959) also observed that when rats were treated with cortisone the distribution of body proteins was similar to that in riboflavin deficiency.

The effects of riboflavin deficiency upon protein metabolism in the rat therefore cannot clearly be ascribed to impairment of pituitary or adrenal function.

\section{SUMMARY}

1. In four experiments young albino rats were divided into three groups with the same mean body-weight. They were given a diet containing $16 \%$ protein. Those of one group were deprived of riboflavin. Those of another were given the same amount of food, and those of the third group were given less food to keep their body-weights within the same range as for those deprived of riboflavin. Depending upon the experiment, the animals were maintained on the regimen for $45-76$ days, at which time the body-weights of those deprived of riboflavin were 10-15\% lower than of those that had received the same amount of food, with riboflavin.

2. At this stage the concentrations of blood haemoglobin, plasma protein, and liver nitrogen were essentially the same in all the animals. When dietary protein depletion, with or without moderate haemorrhage, was imposed, followed by repletion on a diet containing $40 \%$ protein, the concentrations of these three body-protein fractions behaved in the same way regardless of the state of riboflavin nutrition or of bodyweight. They fell and were restored approximately to the same extent and at the same rate.

3. The livers of the riboflavin-deficient rats tended to assume a greater proportion of the body-weight, even during protein repletion, consequently the ratio of liver nitrogen content to body-weight tended to be greater than in animals with adequate riboflavin.

4. It was thus demonstrated that in the rat a deficiency of riboflavin does not impair the synthesis of some of the body's most metabolically important proteins, and that at least in one instance it may be enhanced.

We are indebted to Miss Verna G. Leonard, Mrs R. C. Dicks and Mr M. W. McLeod, who provided technical assistance of high quality and careful and intelligent help with the handling of the animals, a most important function in experiments such as these.

Dr O. H. Gaebler, of the Edsel B. Ford Institute for Medical Research in Detroit, has shown an interest in this work, and we have discussed it with him. We are grateful to him for comments which have been helpful in attempts to interpret the results and to relate them to phenomena of protein metabolism generally. 


\section{REFERENCES}

Addis, T., Poo, L. J. \& Lew, W. (1936a). F. biol. Chem. I15, 111. Addis, T., Poo, L. J. \& Lew, W. (1936b). F. biol. Chem. II5, I 7 . Addis, T., Poo, L. J. \& Lew, W. (1936c). F. biol. Chem. 116, 343. Bartlett, P. D. \& Glynn, M. (1950). F. biol. Chem. 187, 261.

Borgström, S. \& Hammarsten, G. (1944). Acta physiol. scand. 7, 80.

Burch, H. B., Lowry, O. H., Padilla, A. M. \& Combs, A. M. (1956). F. biol. Chem. 223, 29.

Clarke, I. (1953). F. biol. Chem. 200, 69.

Collier, H. B. (1944). Canad. med. Ass. F. 50, 550.

Czaczkes, J. W. \& Guggenheim, K. (1946). F. biol. Chem. 162, 267.

Davenport, C. B. \& Ekas, M. P. (1936). Statistical Methods in Biology, Medicine and Psychology, 4th ed., p. $3^{8}$. New York; John Wiley and Sons Inc.

Ershoff, B. H. (1954). Metabolism, 3, 357.

Evans, G. (1935-6). Amer. F. Physiol. 114, 297.

Forker, B. R. \& Morgan, A. F. (1954). F. biol. Chem. 209, $3 \circ 3$.

Forker, B. R. \& Morgan, A. F. (1955). F. biol. Chem. 217, 659.

Frei, J. \& Ryser, H. (1956). Experientia, 12, 105.

Gornall, A. G., Bardawill, C. J. \& David, M. M. (1949). F. biol. Chem. 177, 751.

Guggenheim, K. \& Diamant, E. J. (1959). Brit. F. Nutr. 13,61.

Harrison, H. C. \& Long, C. N. H. (1945). F. biol. Chem. I6r, 545.

Hiller, J., Plazin, A. \& Van Slyke, D. D. (1948). F. biol. Chem. 176, 1401.

Kaunitz, H., Wiesinger, H., Blodi, F. C., Johnson, R. E. \& Slanetz, C. A. (1954). F. Nutr. 52, 467.

Kleiber, M. \& Jukes, T. H. (1942). Proc. Soc. exp. Biol., N.Y., 49, 34.

Kosterlitz, H. W. (1944). Nature, Lond., 154, 207.

Lewis, R. A., Thorn, G. W., Koepf, G. F. \& Dorrance, S. S. (1942). F. clin. Invest. $21,33$.

Long, C. N. H. (1 942). Endocrinology, 30, 870 .

Long, C. N. H., Katzin, B. \& Fry, E. G. (1940). Endocrinology, 26, 309.

Mayfield, H. L. \& Hedrick, M. T. (1949). $\mathscr{F}$. Nutr. 37, 475.

McQuarrie, E. B. \& Venosa, A. T. (1945). Science, Ior, 493.

Reade, B. \& Morgan, A. F. (1949). Fed. Proc. 8, 392.

Roberts, S. (1953). F. biol. Chem. 200, 77.

Sarett, H. P., Klein, J. R. \& Perlzweig, W. A. (1942). F. Nutr. 24, 295.

Sarett, H. P. \& Perlzweig, W. A. (1943). F. Nutr. 25, 173.

Sherman, H. C. \& Ragan, M. S. (1947). Proc, nat. Acad. Sci., U.S., 33, 266.

Sobel, A. E., Mayer, M. \& Gottfried, S. P. (1944). F. biol. Chem. 156, 355.

Stanier, M. W. (r957). Brit. F. Nutr. Ix, 206.

Wesson, L. G. (1932). Science, 75, 339. 